УДК 330.5:338.432(477)

DOI: https://doi.org/10.37320/2415-3583/12.25

Оленич К.В.

здобувач третього рівня вищої освіти спеціальності 051 «Економіка», Миколаївський національний аграрний університет

\title{
ПРІОРИТЕТНІ НАПРЯМИ ПРОЦЕСУ ДЕЦЕНТРАЛІЗАЦІї
}

У статті розглянуто напрями та пріоритети розвитку процесу децентралізації в Україні. Визначено мету деценттралізації, яка полягає у розширенні повноважень органів місцевого самоврядування громад, а також фінансовому заохоченні проиесів добровільного об'єднання територіальних громад, створенні нормативно-правовоі основи формування. Узагальнено ключові етапи побудови ефективної системи територіальної організації влади, визначено роль децентралізації у розвитку економіки країни, регіону, території. Встановлено принципи процесу децентралізації, які грунтуються на добровільному об'єднанні сільських та селищних рад. Доведено, щуо ефективність децентралізаиії проявляється через реалізацію можливостей та сформоване законодавче врегулювання иьвого процесу з урахуванням взаємодї між органами державної влади й місчевого самоврядування та жителів громади загалом. Основні наукові результати, отримані під час дослідження, вказують на позитивне сприяння процесу децентралізацій на соиіально-економічний розвиток в Україні. Пріоритетність розвитку дорадництва спонукатиме до забезпечення дієвості запровадження управлінських рімень, системності заходів щзодо зменшення кількості та масштабів обмежень, результативності реформ, розвитку місиевого самоврядування.

Ключові слова: децентралізація, об'єднана територіальна громада, сочіально-економічний потенціал, дорадництво, розвиток інфраструктури.

Постановка проблеми. Територіальні трансформації та реформи відбуваються через процес децентралізації державного управління в Україні, що має особливий інтерес у контексті розвитку місцевого самоврядування. Організація ефективного процесу децентралізації є складним завданням через необхід- ність формування дієвих інститутів місцевого самоврядування, регіональні особливості, ментальність. Трансформаційні процеси спонукають до створення релевантної нормативно-правової бази, накопичення певних знань, вмінь та досвіду проведення відповідної політики, а також реалізації практичних навичок 
у галузі місцевого самоврядування за досвідом інших держав світу.

Аналіз останніх досліджень і публікацій. Вивченням питань щодо пріоритетних напрямів розвитку процесу децентралізації в Україні займаються багато вчених, зокрема Я. Жаліло [1], О. Бориславська [2], I. Гончаренко, А. Ключник, I. Заверуха, І. Волохова [3], Л. Ярема [4], В. Пальчук [5], Е. Захарченко, О. Шевченко. Автори досліджували вплив децентралізації на розвиток регіонів. Основну увагу приділено розвитку реформи децентралізації в Україні, визначенню пріоритетних напрямів та узагальненню іiі результатів. Дослідження трансформаційних процесів у різних регіонах відбувається 3 огляду на певні особливості, зокрема ментальні, й потребує подальшого вивчення та узагальнення з теоретичної та практичної точок зору.

Мета статті полягає в дослідженні особливостей та визначенні сучасних тенденцій децентралізації з урахуванням адаптаційних змін, окресленні пріоритетних напрямів іiї розвитку як передумови модернізації системи місцевого самоврядування громад.

Виклад основного матеріалу. Створення передумов до системного та комплексного розвитку сільських територій, спрямованого на формування робочих місць, покращення умов життя населення та поліпшення інфраструктури є стратегічною метою децентралізації. Відповідні зміни закладено в Концепції реформування місцевого самоврядування та територіальної організації влади в Україні, яка була ухвалена Кабінетом Міністрів України 1 квітня 2014 року [11].

Стратегія сталого розвитку «Україна - 2020», яка схвалена Указом Президента у січні 2015 року [6], додала децентралізацію до переліку першочергових реформ, необхідних для забезпечення європейських стандартів життя. Метою було визначено відхід від централізованої моделі управління в державі, забезпечення спроможності місцевого самоврядування та побудови ефективної системи територіальної організації влади в Україні, реалізацію повною мірою положень Європейської хартії місцевого самоврядування, принципів субсидіарності, повсюдності й фінансової самодостатності місцевого самоврядування [1]

Перспективним планом, затвердженим Кабінетом Міністрів України, передбачалися формування об’єднаних територіальних громад у 23 областях, ство-

\begin{tabular}{|c|c|c|c|}
\hline \multicolumn{4}{|c|}{ ДЕЦЕНТРАЛІЗАЦІЯ } \\
\hline$\downarrow$ & $\nabla$ & $\downarrow$ & $\nabla$ \\
\hline $\begin{array}{l}\text { Посилення ролі } \\
\text { місцевого } \\
\text { самоврядування }\end{array}$ & $\begin{array}{c}\text { Передача «на } \\
\text { місця» } \\
\text { максимальної } \\
\text { кількості } \\
\text { повноважень, які } \\
\text { органи місцевого } \\
\text { самоврядування } \\
\text { здатні виконати }\end{array}$ & $\begin{array}{c}\text { Зміна положення } \\
\text { про } \\
\text { адміністративно- } \\
\text { територіальний } \\
\text { устрій }\end{array}$ & $\begin{array}{c}\text { Врахування } \\
\text { історичних, } \\
\text { економічних, } \\
\text { екологічних та } \\
\text { культурних } \\
\text { особливостей під } \\
\text { час планування } \\
\text { розвитку громад }\end{array}$ \\
\hline \multicolumn{2}{|c|}{$\begin{array}{l}\text { Створення об’єднаних } \\
\text { територіальних громад }\end{array}$} & \multicolumn{2}{|c|}{$\begin{array}{c}\text { Гарантія наділення місцевого } \\
\text { самоврядування достатніми } \\
\text { повноваженнями та ресурсами }\end{array}$} \\
\hline
\end{tabular}

Рисунок 1 - Очікувані результати процесу децентралізації

Джерело: узагальнено автором на основі джерел [2; 3; 5$]$ рення 1304 об'єднаних територіальних громад, у які мали увійти 9043 населених пунктів. Фактично цим об'єднанням заплановано було охопити майже $82,0 \%$ загальної площі України з 28,8 млн. громадян, що становить 73,5\% усього населення держави [1].

Задля реалізації стратегії необхідно було внести зміни до чинного законодавства України. Так, було прийнято Закон України «Про добровільне об'єднання територіальних громад», визначено, що основним принципом адміністративно-територіальної реформи $\epsilon$ принцип добровільності. Цей принцип акцентував свою увагу на важливих рисах функціонування адміністративно-територіальних об'єднаннях, а саме перспективах розвитку.

Основною метою реформування було розширення повноважень органів місцевого самоврядування громад, фінансове заохочення процесів добровільного об'єднання громад [2].

Децентралізація мала на меті прискорення розвитку, надання можливостей урахування особливостей територій. Основні зміни, які відбулися внаслідок децентралізації, узагальнено на рис. 1. Новим етапом процесу децентралізації став План заходів Уряду з реалізації нового етапу реформування місцевого самоврядування та територіальної організації влади на період до 2021 року [12].

Ключовим завданням цього етапу є затвердження нової територіальної основи для діяльності органів влади на рівні громад шляхом завершення процесу добровільного об'єднання громад. Передбачено затвердження перспективних планів об'єднаних територіальних громад усіх областей, сприяння добровільному об'єднанню громад, завершення створення адміністративно-територіальних одиниць базового рівня.

Виявлено, що наслідком процесу децентралізації є створення 1042 об'єднаних територіальних громад, які охоплюють 40\% території України. Основні обмеження під час реформування узагальнено на рис. 2 .

Сформована нормативна база процесу об'єднання територіальних громад має певні відповідності. Зміни, які були внесені до Закону України «Про добровільне об'єднання територіальних громад» щодо забезпечення доступності необхідними публічними послугами, були спрямовані на вдосконалення правового регулювання питання забезпечення доступності необхідними публічними послугами (медичні послуги, адміністративні послуги, банківські послуги, відкриття відділень державного банку, поштові послуги, відкриття відділень поштового зв'язку) тощо. У затверджених змінах не були виділені дошкільні навчальні заклади та заклади соціального захисту, що спонукає до певних обмежень у фінансуванні [8].

Задля активізації процесу необхідно забезпечити підвищення конкурентоспроможності економічно активного населення за допомогою 
навчання шляхом залучення експертів, створення та розширення інститутів розвитку (вибір пріоритетів інвестування місцевими громадами), підвищити мобільність робочої сили на ринку праці та вдосконалити регулювання трудової міграції, сприяти використанню потенціалу транскордонної співпраці $[1 ; 4 ; 9]$.

Задля вирішення вищезазначених обмежень введено в дію Закон України «Про сільськогосподарську дорадчу діяльність» [10], який передбачає правові засади здійснення сільськогосподарської дорадчої діяльності. Підвищення конкурентоспроможності економічно активного населення за допомогою навчання значною мірою залежить від динамічності освоєння нових технологій, використання ринкової кон'юнктури, низки організаційних змін, необхідних для поступального розвитку. Саме цю роль виконує система сільськогосподарського дорадництва, головною метою якої $\epsilon$ сприяння покращенню добробуту сільського населення та розвитку сільських територій через підвищення рівня знань i вдосконалення практичних навичок сільського населення та сільськогосподарських товаровиробників [13].

Основні методи та завдання дорадчої діяльності визначені у Законі України «Про сільськогосподарську дорадчу діяльність» та представлені на рис. 3.

Так, функціонування в Україні сільськогосподарських дорадчих служб, їхня дієва співпраця у сфері дорадчих послуг на постійній основі $€$ виконаною частиною угоди Асоціації між Україною та Європейським Союзом. Саме тому розбудова системи сільськогосподарського дорадництва $є$ невід'ємною складовою частиною євроінтеграційного процесу.

Важливим питанням процесу децентралізації $\epsilon$ побудова ефективної системи територіальної організації влади в Україні для якісного та комфортного проживання людей. Етапи розвитку включають створення об'єднаної територіальної громади, розвиток місцевого самоврядування, передачу ресурсів, передачу повноважень на місцях, підвищення фінансової спроможності, прискорення економічної та інвестиційної привабливості територій. Саме в такій ієрархічній послідовності має відбуватися ефективна система внесено низку змін до Закону України «Про

добровільне об'єднання територіальних громад», які $\epsilon$

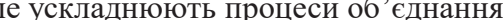
територіальних громад

неможливість чітко встановити, як впливає ормування об’єднаних територіальних громад на

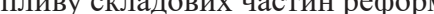
середовища громадян

не виставлені межі управлінських свобод об'єднаних територіальних громад; внаслідок нерозв'язання питання 3 наглядом за діяльністю громад 1

рішеннями їх управлінських органів ці питання передано на розсуд самих громад

Рисунок 2 - Основні обмеження реформи децентралізації

Джерело: узагальнено автором на основі джерел $[1 ; 8]$

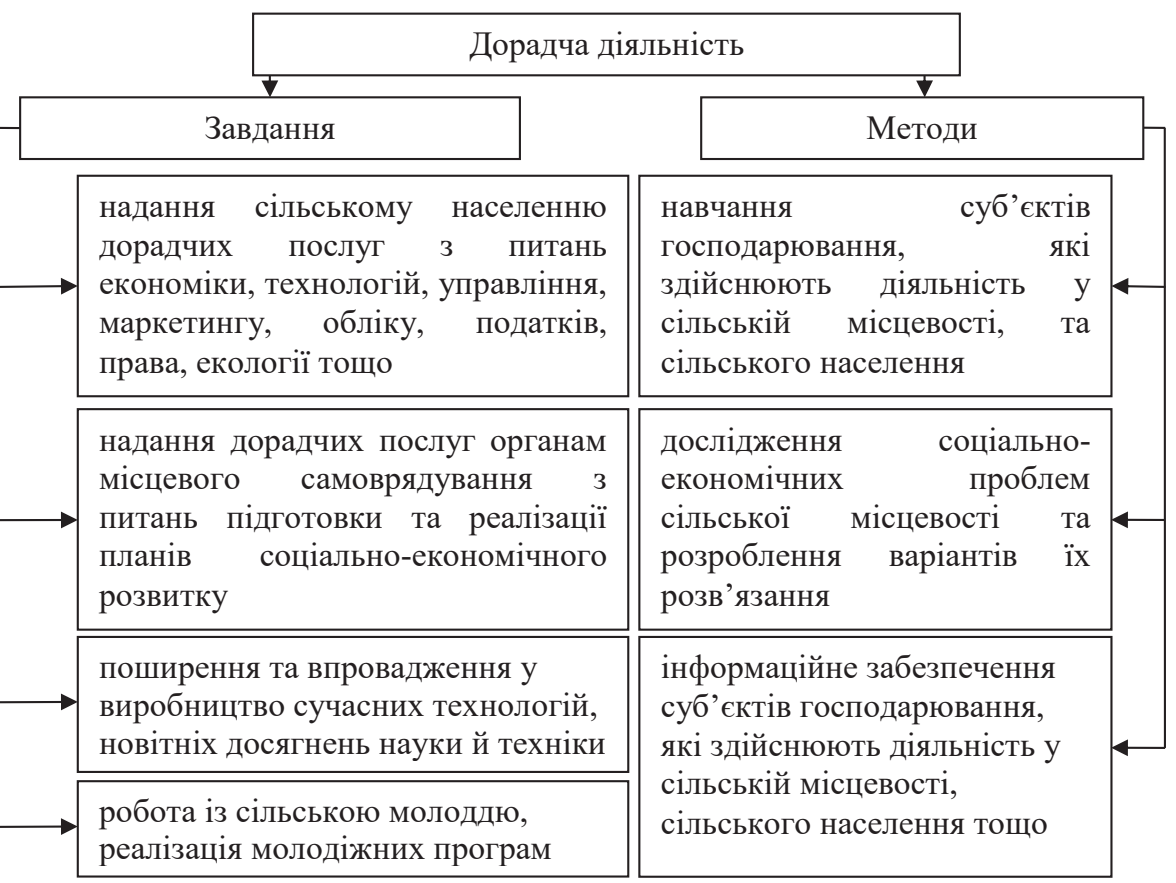

\section{Рисунок 3 - Основні завдання та методи дорадчої діяльності}

\section{Джерело: узагальнено автором на основі джерел [10; 13$]$}

територіальної організації влади для значного посилення спроможності вирішувати питання місцевого розвитку, ефективно виконувати свої повноваження та надавати якісні послуги людям. Розвиток об'єднаних територіальних громад відповідно до вищезазначених етапів дасть можливість новоствореним громадам успішно реалізувати програму децентралізації.

Європейський досвід засвідчує практику ефективного вирішення багатьох територіальних проблем, актуальних для України. Зокрема, слід відзначити досвід щодо реалізації такого основоположного принципу державного управління, як принцип субсидіарності, за яким рішення мають прийматися на якомога ближчому до громадян рівні (рівень місцевого 
самоврядування). У багатьох європейських країнах цей принцип $є$ основоположним у політиці децентралізації, що проводиться 3 1980-х років (тенденція до децентралізації спостерігається в останні десятиліття в більшості як розвинених країн, так і країн, що розвиваються). Слід звернути увагу також на інші ініціативи щодо реструктуризації територіальних одиниць, розподілу компетенцій між ними, розвитку великих міських агломерацій тощо.

Таким чином, об'єднана територіальна громада є системою, в якій джерела наповнення бюджету, інфраструктурні та кадрові ресурси є достатніми для вирішення іï органами місцевого самоврядування питань місцевого значення, передбачених законодавством, в інтересах жителів громади. Об'єднані територіальні громади, працюючи за новою системою субвенції маючи доступ до коштів Державного фонду регіонального розвитку, сприяють отриманню нових джерел доходів внаслідок розширення їхніх компетенцій у сфері земельних відносин, реєстраційних процедур, контролю тощо.

Саме тому пріоритетні напрями процесу децентралізації мають бути пов'язані зі знаннями, вміннями та практичним досвідом, який дасть змогу використовувати найкращі практики цього трансформаційного процесу щодо підвищення рівня відповідальності та ролі місцевого самоврядування. Пріоритетність розвитку дорадництва спонукатиме до забезпечення дієвості запровадження управлінських рішень, системності заходів щодо зменшення кількості та масштабів обмежень, результативності реформ, розвитку місцевого самоврядування.

Висновки. У проведеному дослідженні розглянуто напрями та пріоритети розвитку процесу децентралізації в Україні. Встановлено, що мета децентралізації полягає в розширенні повноважень органів місцевого самоврядування громад, а також фінансовому заохоченні процесів добровільного об'єднання територіальних громад, створенні нормативно-правової основи формування.

Доведено, що, незважаючи на безсумнівні позитивні результати трансформації місцевого самоврядування, залишилися невирішеними багато важливих питань. Всупереч сподіванням реформаторів адміністративно-територіальний устрій не став простішим i зрозумілішим. Створення численних об'єднань 3 досить різнорідними статусами ускладнює систему адміністративного управління. При цьому більшість правових норм і регламентацій, які були прийняті й торкнулися територіальних громад, не враховували навантаження на місцеві бюджети. За цих умов варто звернути увагу на перерозподіл відповідальності (i, відповідно, ресурсів) з верхнього рівня управління на нижній. При цьому проблема територіальної роздробленості й особливо розвитку міжмуніципального співробітництва має велике значення. 3 огляду на слабке ресурсне забезпечення більшості муніципальних утворень і високий рівень їхньої дотаційності постановка питання про розвиток різних форм міжмуніципального співробітництва $є$ актуальною. Слід звернути увагу також на ще одне спрямування реформ. Йдеться про підвищення ролі міст у місцевому розвитку за рахунок створення міжмуніципальних об'єднань, що включають міста та прилеглі до них території. Реформа була зосереджена на організації самоврядування у сільській місцевості, а міська проблематика майже не розглядалася. Тим часом міста є центрами економічного зростання, їхній успішний розвиток вважається важливою передумовою забезпечення конкурентоспроможності регіонів та держави.

Існує також проблема пошуку розумного балансу між централізацією та децентралізацією управління. Останніми роками одержавлення інституту місцевого самоврядування та його вбудовування у вертикаль влади сприяли зміцненню тенденції до централізаціiі, що ускладнило процес становлення вітчизняного інституту самоврядування.

3 огляду на наявні обмеження, які виникають під час трансформаційних процесів, важливими завданнями $є$ вивчення світового досвіду, впровадження найкращих практик процесу децентралізації, розвитку місцевого самоврядування та підвищення рівня відповідальності, що допоможе уникнути додаткових обмежень і сформувати дієву систему управління територіальним розвитком. Знання та досвід можуть бути поєднані 3 практичною реалізацією, зокрема, через дорадництво. Практичний досвід та адаптаційні підходи дадуть змогу визначити напрями та пріоритети розвитку процесу децентралізації в країні, вектор ефективного й відповідального розвитку місцевого самоврядування.

\section{Список використаних джерел:}

1. Децентралізація влади: порядок денний на середньострокову перспективу : аналітична доповідь / Я. Жаліло, О. Шевченко, В. Романова та ін. Київ : Національний інститут стратегічних досліджень, 2019. 192 с.

2. Бориславська О., Заверуха I., Захарченко Е. та ін. Децентралізація публічної влади: досвід європейських країн та перспективи України / Швейцарсько-український проект «Підтримка децентралізації в Україні - DESPRO. Київ : TOB «Софія», 2012. $128 \mathrm{c}$.

3. Волохова І. Місцеві фінанси та перспективи поглиблення фінансової децентралізації Україні : монографія. Одеса : Атлант, 2014. 462 с.

4. Ярема Л. Роль об'єднаних територіальних громад Тернопільщини у розвитку сільських територій. Агросвіт. 2019. № 24. C. 71-76.

5. Пальчук В. Розвиток економічного потенціалу громад у рамках реформи з децентралізації. Україна: події, факти, коменmapi. 2018. Вип. 11. С. 38-50. URL: http://nbuviap.gov.ua/images/ukraine/2018/ukr11.pdf (дата звернення: 17.02.2020).

6. Про Стратегію сталого розвитку «Україна - 2020» : Указ Президента України від 12 січня 2015 року № 5 / Верховна Рада України. URL: https://zakon.rada.gov.ua/laws/show/5/2015\#n10 (дата звернення: 17.02.2020).

7. Про Цілі сталого розвитку України на період до 2030 року : Указ Президента України від 30 вересня 2019 року № $722 /$ 2019 / Верховна Рада України. URL: https://zakon.rada.gov.ua/laws/show/722/2019\#Техt (дата звернення: 18.06.2020).

8. Економіко-правові аспекти сталого розвитку: держава, регіон, місто : матеріали Першої міжнародної науково-практичної конференції (7 червня 2019 року, м. Київ) / наук. ред. В. Устименко. Київ : НАН України ; Інститут економіко-правових досліджень, 2019. 208 с. 
9. Про добровільне об’єднання територіальних громад : Закон України від 5 лютого 2015 року № 157-VIII / Верховна Рада України. URL: https://zakon.rada.gov.ua/laws/show/157-19 (дата звернення: 17.02.2020).

10. Про сільськогосподарську дорадчу діяльність : Закон України від 17 червня 2004 року № 1807-IV / Верховна Рада України. URL: https://zakon.rada.gov.ua/laws/show/1807-15 (дата звернення: 17.02.2020).

11. Про схвалення Концепції реформування місцевого самоврядування та територіальної організації влади в Україні : Розпорядження Кабінету Міністрів України від 1 квітня 2014 року № 333-p / Верховна Рада України. URL: https://zakon.rada.gov.ua/laws/show/333-2014-\%D1\%80\#Text (дата звернення: 18.06.2020).

12. Про затвердження плану заходів з реалізації нового етапу реформування місцевого самоврядування та територіальної організації влади в Україні на 2019-2021 роки : Розпорядження Кабінету Міністрів України від 23 січня 2019 року № 77-р / Верховна Рада України. URL: https://zakon.rada.gov.ua/laws/show/77-2019-\%D1\%80\#Text (дата звернення: 18.06.2020).

13. Ровний В. Проблеми правового регулювання діяльності дорадників та експертів-дорадників сільськогосподарської дорадчої діяльності. Наме право. 2015. № 5. 124 с.

\section{References:}

1. Zhalilo Ya., Shevchenko O., Romanova V. (2019) Decentralizaciya vlady: poryadok dennyj na serednostrokovu perspektyvu. [Decentralization of power: an agenda for the medium term]. Analytical report. National Institute for Strategic Studies, p. 192.

2. Boryslavska O., Zaverukha I., Zakharchenko E. (2012) Decentralizaciya publichnoyi vlady: dosvid yevropejskyh krayin ta perspektyvy Ukrayiny. [Decentralization of public power: the experience of European countries and prospects of Ukraine]. SwissUkrainian project "Support to decentralization in Ukraine - DESPRO", p. 128.

3. Volohova I. (2014) Miscevi finansy ta perspektyvy poglyblennya finansovoyi decentralizaciyi Ukrayini [Local finances and prospects for deepening the financial decentralization of Ukraine]. Monograph, p. 462.

4. Yarema L. (2019) Rol obyednanyh terytorialnyh gromad ternopilshhyny u rozvytku silskyh terytorij [The role of united territorial communities of Ternopil region in the development of rural areas]. Agrosvit, pp. 71-76.

5. Palchuk V. (2018) Rozvytok ekonomichnogo potencialu gromad u ramkah reformy z decentralizaciyi. Ukrayina: podiyi, fakty, komentari [Development of economic potential of communities in the framework of decentralization reform. Ukraine: events, facts, comments]. Vip. 11, pp. 38-50. URL: http://nbuviap.gov.ua/images/ukraine/2018/ukr11.pdf (accessed: 17 February 2020).

6. Pro Strategiyu stalogo rozvytku "Ukrayina - 2020" [On the Strategy of Sustainable Development "Ukraine - 2020"]. Decree of the President of Ukraine of 12.01.2015 № 5/2015 / The Verkhovna Rada of Ukraine. URL: https://zakon.rada.gov.ua/laws/ show/5/2015\#n10 (accessed: 17 February 2020).

7. Pro Cili stalogo rozvytku Ukrayiny na period do 2030 roku [On the Goals of Sustainable Development of Ukraine for the period up to 2030]. Decree of the President of Ukraine of 30.09.2019 № 722/2019 / The Verkhovna Rada of Ukraine. URL: https://zakon.rada.gov.ua/laws/show/722/2019\#Text (accessed: 18 June 2020).

8. Ustimenko V. (2019) Ekonomiko-pravovi aspekty stalogo rozvytku: derzhava, region, misto [Economic and legal aspects of sustainable development: state, region, city]. Materials of the First International Scientific and Practical Conference / Nauk. ed. NAS of Ukraine. Inst. Of Economic and Legal Research, p. 208.

9. Pro dobrovilne ob'yednannya terytorialnyh gromad [On voluntary association of territorial communities]. Law of Ukraine of 05.02.2015 № 157-VIII / The Verkhovna Rada of Ukraine. URL: https://zakon.rada.gov.ua/laws/show/157-19 (accessed: 17.02.2020).

10. Pro silskogospodarsku doradchu diyalnist [On agricultural advisory activities]. Law of Ukraine of 17.06.2004 № 1807-IV / The Verkhovna Rada of Ukraine. URL: https://zakon.rada.gov.ua/laws/show/1807-15 (accessed: 17 February 2020).

11. Pro shvalennya Koncepciyi reformuvannya miscevogo samovryaduvannya ta terytorialnoyi organizaciyi vlady v Ukrayini [On approval of the Concept of reforming local self-government and territorial organization of power in Ukraine]. Order of the Cabinet of Ministers of Ukraine dated 01.04.2014 № 333 / The Verkhovna Rada of Ukraine. URL: https://zakon.rada.gov.ua/laws/ show/333-2014-\%D1\%80\#Text (accessed: 18 June 2020).

12. Pro zatverdzhennya planu zahodiv z realizaciyi novogo etapu reformuvannya miscevogo samovryaduvannya ta terytorialnoyi organizaciyi vlady v Ukrayini na 2019-2021 roky [On approval of the action plan for the implementation of the new stage of reforming local self-government and territorial organization of power in Ukraine for 2019-2021]. Order of the Cabinet of Ministers of Ukraine of January 23, 2019 № 77 / Verkhovna Rada of Ukraine. URL: https://zakon.rada.gov.ua/laws/show/77-2019-\%D1\%80\#Text (accessed: 18 June 2020).

13. Rovny V. (2015) Problemy pravovogo regulyuvannya diyalnosti doradnykiv ta ekspertiv-doradnykiv silskogospodarskoyi doradchoyi diyalnosti [Problems of legal regulation of the activities of advisers and expert advisors of agricultural advisory activities]. Our right, № 5, p. 124. 
Olenich Ksenia

Mykolaiv National Agrarian University

\section{PRIORITY DIRECTIONS OF THE DECENTRALIZATION PROCESS}

The article under consideration deals with the directions and priorities of the decentralization process development in Ukraine. The purpose of decentralization has been defined, which consists in accretion of powers of bodies of local self-government of communities, and also financial encouragement of processes of voluntary association of territorial communities, creation of a normative-legal basis of formation. The peculiarities of the decentralization process development have been outlined and the current tendencies of decentralization have been determined taking into account the adaptive changes, the priority directions of its development have been characterized as preconditions for the modernization of the local self-government system. The preconditions for the creation of systemic and integrated development of rural areas, through the direction of job creation, improvement of living conditions and improvement of infrastructure have been identified. The key stages of building an effective system of territorial organization of power have been summarized, the role of decentralization in the development of the economy of the country, region, and territory has been determined. The principles of the decentralization process have been established, which are based on the voluntary association of village and urban-type settlement councils. It has been proved that the effectiveness of decentralization is manifested through the realization of opportunities and the current legislative regulation of this process, taking into account the interaction between public authorities and local governments and the community as a whole. It has been established that the European experience gives the practice of effective solution of many territorial problems relevant to Ukraine, especially the experience in the implementation of the principle of subsidiarity, according to which decisions should be made as close as possible to citizens (i.e. local government level). Key research insights indicate a positive contribution to the process of decentralization to socio-economic development in Ukraine. The priority of development of advisory will encourage ensuring the effectiveness of the implementation of management decisions, systematic measures to reduce the number and scope of restrictions, the effectiveness of reforms, the development of local self-government.

Key words: decentralization unified territorial community, socio-economic potential, advisory, infrastructure development.

JEL classification: R11, R58 